\title{
What transposable elements are differentially translated in lung cancer?
}

\author{
Wan R Yang ${ }^{1,2^{*}}$, Eric W Mills ${ }^{3}$, Nemanja Rodic ${ }^{1}$, Nicholas T Ingolia ${ }^{3}$, Jef D Boeke ${ }^{4}$, Hyam I Levitsky ${ }^{1,2}$ \\ Kathleen $\mathrm{H}$ Burns ${ }^{1,2,3}$ \\ From Society for Immunotherapy of Cancer 28th Annual Meeting \\ National Harbor, MD, USA. 8-10 November 2013
}

Transposable element (TE) expression is generally silent in somatic tissues, due to significant genomic methylation and other redundant methods of silencing. Cancer tissues, however, exhibit a marked decrease in methylation throughout the genome, which can result in de-repression of transposable element transcription. Because of this phenomenon, TEs may be tumor-specific antigens for use as potential biomarkers and vaccine targets. Lung cancer in particular is in dire need of early screening tools and treatment; the five-year survival rate is $16 \%$. Ideal biomarkers and vaccine targets for lung cancer would be proteins or polypeptides that can be recognized by the immune system. However, TEs are subject to multiple posttranscriptional silencing mechanisms, such that increased hypomethylation does not necessarily result in increased polypeptide expression. Although evidence of increased transposable element RNAs and proteins in cancer tissues (in particular LINE-1 and HERV-K) exist in the literature, translation of other retrotransposon-encoded intermediates and other repetitive transcripts has not been thoroughly investigated. To this end we selectively sequenced translated TE sequences in a conditional mouse model of lung cancer, using ribosomal profiling. Comparing ribosomal footprints of healthy wild-type and transgenic cancerous lung tissues allows us to identify differentially translated elements.
'Pathology, Johns Hopkins University School of Medicine, Baltimore, MD, USA

Full list of author information is available at the end of the article
Authors' details

${ }^{1}$ Pathology, Johns Hopkins University School of Medicine, Baltimore, MD, USA. ${ }^{2}$ Oncology, Johns Hopkins University School of Medicine, Baltimore, MD, USA. ${ }^{3}$ Embryology, Carnegie Institution for Science, Baltimore, MD, USA. ${ }^{4}$ Molecular Biology and Genetics, Johns Hopkins University School of Medicine, Baltimore, MD, USA.

Published: 7 November 2013

doi:10.1186/2051-1426-1-S1-P139

Cite this article as: Yang et al: What transposable elements are differentially translated in lung cancer? Journal for ImmunoTherapy of Cancer 2013 1(Suppl 1):P139.
Submit your next manuscript to BioMed Central and take full advantage of:

- Convenient online submission

- Thorough peer review

- No space constraints or color figure charges

- Immediate publication on acceptance

- Inclusion in PubMed, CAS, Scopus and Google Scholar

- Research which is freely available for redistribution

Submit your manuscript at www.biomedcentral.com/submit
() Biomed Central
C Biomed Central

(c) 2013 Yang et al; licensee BioMed Central Ltd. This is an Open Access article distributed under the terms of the Creative Commons Attribution License (http://creativecommons.org/licenses/by/2.0), which permits unrestricted use, distribution, and reproduction in any medium, provided the original work is properly cited. 